\title{
Phosphorus Load to Surface Water from Bank Erosion in a Danish Lowland River Basin
}

\author{
Brian Kronvang, ${ }^{*}$ Joachim Audet, Annette Baattrup-Pedersen, Henning S. Jensen, and Søren E. Larsen
}

Phosphorus loss from bank erosion was studied in the catchment of River Odense, a lowland Danish river basin, with the aim of testing the hypothesis of whether stream banks act as major diffuse phosphorus (P) sources at catchment scale. Furthermore, the study aimed at analyzing the impact of different factors influencing bank erosion and $\mathrm{P}$ loss such as stream order, anthropogenic disturbances, width of uncultivated buffer strips, and the vegetation of buffer strips. A random stratified procedure in geographical information system (GIS) was used to select two replicate stream reaches covering different stream orders, channelized vs. naturally meandering channels, width of uncultivated buffer strips $(\leq 2 \mathrm{~m}$ and $\geq 10 \mathrm{~m}$ ), and buffer strips with different vegetation types. Thirty-six 100-m stream reaches with 180 bank plots and a total of 3000 erosion pins were established in autumn 2006, and readings were conducted during a 3-yr period (2006-2009). The results show that neither stream size nor stream disturbance measured as channelization of channel or the width of uncultivated buffer strip had any significant $(p<0.05)$ influence on bank erosion and $P$ losses during each of the 3 yr studied. In buffer strips with natural trees bank erosion was significantly $(p<0.05)$ lower than in buffer strips dominated by grass and herbs. Gross and net $\mathrm{P}$ input from bank erosion amounted to 13.8 to 16.5 and 2.4 to 6.3 t P, respectively, in the River Odense catchment during the three study years. The net $\mathrm{P}$ input from bank erosion equaled 17 to $29 \%$ of the annual total P export and 21 to $62 \%$ of the annual export of $\mathrm{P}$ from diffuse sources from the River Odense catchment. Most of the exported total $\mathrm{P}$ was found to be bioavailable (71.7\%) based on a P speciation of monthly suspended sediment samples collected at the outlet of the river basin. The results found in this study have a great importance for managers working with $\mathrm{P}$ mitigation and modeling at catchment scale.

Copyright $\odot 2012$ by the American Society of Agronomy, Crop Science Society of America, and Soil Science Society of America. All rights reserved. No part of this periodical may be reproduced or transmitted in any form or by any means, electronic or mechanical, including photocopying, recording, or any information storage and retrieval system, without permission in writing from the publisher.

J. Environ. Qual. 41:304-313 (2012)

doi:10.2134/jeq2010.0434

Posted online 14 July 2011

Freely available through the author-supported open-access option.

Received 3 Oct. 2010.

*Corresponding author (bkr@dmu.dk).

(c) ASA, CSSA, SSSA

5585 Guilford Rd., Madison, WI 53711 USA
Q UANTIFICATION OF PHOSPHORUS (P) sources to surface waters at catchment scale involves a range of both point and diffuse emissions (Sharpley and Rekolainen, 1997; Heathwaite et al., 2005; Kronvang et al., 2007). In many developed countries around the world, diffuse P losses are today the dominant source in $\mathrm{P}$ budgets at river basin or catchment scale (Kronvang et al., 2007; Maguire et al., 2009). River basin managers need to establish knowledge of major diffuse P sources to cost-effectively combat the eutrophication problem in surface waters (Haygarth et al., 2009). Phosphorus models are one of the methods used by river basin managers to quantify the magnitude of different $\mathrm{P}$ pathways (Schoumans et al., 2009). Stream bank erosion is, however, seldom included in these models even though recent investigations have suggested bank erosion to be an important P source (Hasholt, 1988; Laubel et al., 2003; Kronvang et al., 2005; Zaimes et al., 2008).

Hundreds of River Basin Management Plans are currently being developed and adopted as part of the European Union's Water Framework Directive to secure at least a good ecological quality of all natural water bodies (EC, 2000). Phosphorus loadings from point and nonpoint sources are one of the most important water quality problems in surface waters. For example, the objectives for a good ecological quality in Danish shallow and deep lakes are set for summer chlorophyll $a$ concentrations being transformed into an in-lake average summer total $\mathrm{P}$ concentration of $25 \mu \mathrm{g} \mathrm{P} \mathrm{L}{ }^{-1}$ for deep lakes and 70 $\mu \mathrm{g} \mathrm{P} \mathrm{L}{ }^{-1}$ for shallow lakes (Danish Ministry of Environment, 2010). The maximum allowable concentrations of total $P$ in inflowing waters to lakes can be calculated for each individual lake, utilizing lake models that takes the in-lake retention into consideration (Hejzlar et al., 2009) to not exceed the target concentrations for lake water $\mathrm{P}$. The setting of such a strict ecologically driven $\mathrm{P}$ threshold for inflowing waters to lakes demands a knowledge on the $\mathrm{P}$ budget, importance of $\mathrm{P}$ sources, and the magnitude of diffuse $\mathrm{P}$ pathways within the lake catchment. Another important factor is the bioavailability of the P forms that enters the lake (e.g., Egemose and Jensen, 2009). Managers need to quantify the P loss from all land uses in the catchment, including the importance of fluvial erosion and subaerial processes causing erosion and loss of sediment

B. Kronvang, J. Audet, A. Baattrup-Pedersen, and S.E. Larsen, Dep. of Bioscience, Faculty of Science and Technology, Aarhus Univ., Vejlsøvej, Silkeborg, Denmark; H.S. Jensen, Institute of Biology, Univ. of Southern Denmark, Odense, Denmark. Assigned to Associate Editor Marc Stutter. 
and particulate $\mathrm{P}$ from cohesive stream banks (Lawler et al., 1999; Couper, 2003; Julian and Torres, 2006; Lawler, 2008).

Bank erosion is a natural fluvial process and therefore the input of $\mathrm{P}$ with bank material may be regarded solely as a background $\mathrm{P}$ source under certain conditions. Large-scale drainage schemes of riparian agricultural land converting natural meandering streams to straightened, deepened, and widened streams, and the subsequent change and reduction in vegetation cover along streams, will decrease bank stability and enhance the bank erosion process (Lawler et al., 1999; Laubel et al., 2003; Zaimes et al., 2008; Collins et al., 2010; Raven et al., 2010). Moreover, decades of intensive agricultural production in the drained riparian areas along streams being either in crop rotation or grazed pastures have increased the P content of stream margin soils (Collins and Walling, 2007; Hoffmann et al., 2009; Stutter et al., 2009). The importance of the different natural and anthropogenic factors influencing bank erosion and the subsequent sediment and P loss to surface waters is seldom investigated, and more knowledge about the magnitude of this source is therefore of great interest. The objective of this study was to compare stream bank erosion and sediment and $\mathrm{P}$ loss along reaches representing a gradient in watercourse forms (meandering contra channelized), stream types (three groups of stream orders; Strahler, 1957), undisturbed buffer zone width (narrow and wide), and buffer zone vegetation (low and high). Based on stream and buffer zone type, we hypothesized that the magnitude of stream bank erosion would generally increase with stream order, increase with anthropo-

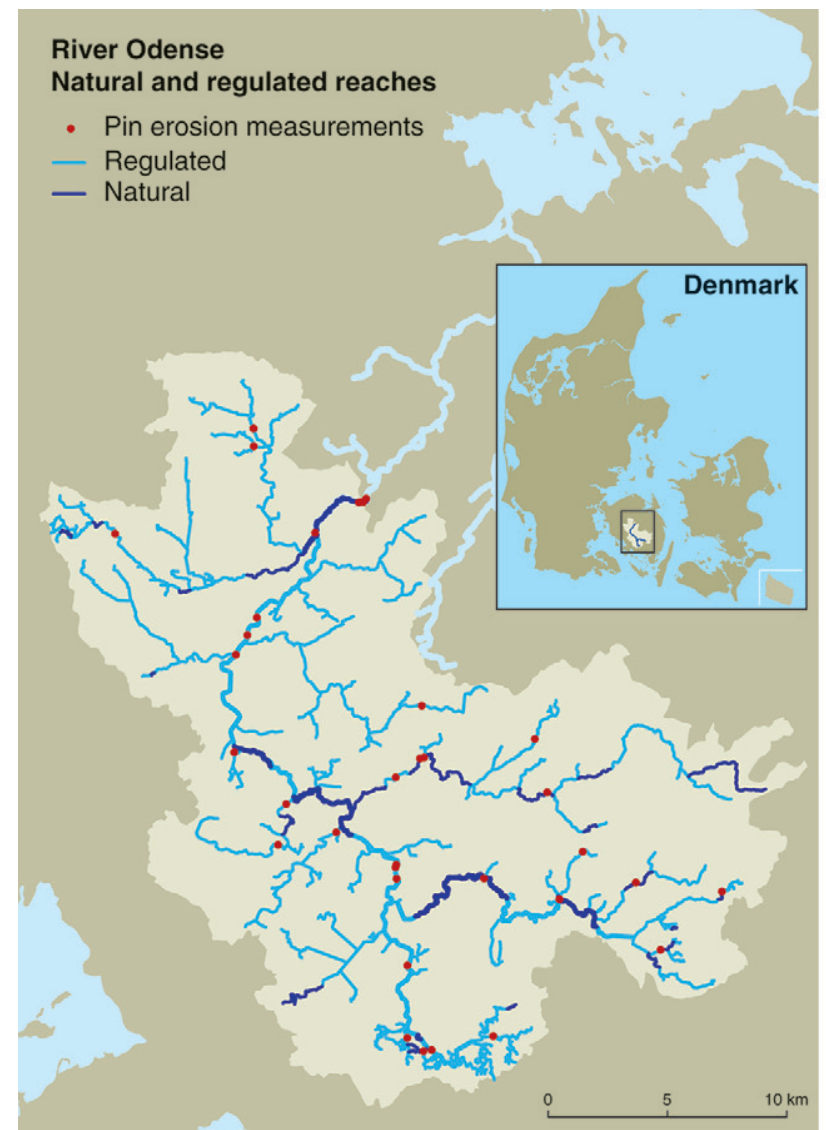

genic disturbance of the stream channel and buffer zone vegetation, and decrease with width of uncultivated buffer zone. We also aim at quantifying the importance of bank erosion as a P source in this studied lowland River Odense catchment by establishing a P budget comparing the gross and net export of $P$ from bank erosion with the measured total $P$ export from the catchment. Finally, we utilized a chemical sequential extraction technique to evaluate the bioavailability of particulate $\mathrm{P}$ in bank sediment and suspended sediment transported in the river to downstream recipients as lakes and estuaries.

\section{Materials and Methods}

\section{Study Catchment}

The River Odense at Kratholm drains a catchment of $486 \mathrm{~km}^{2}$ on the island of Funen, Denmark (Fig. 1). The most common landscape feature is moraine plains covered by moraine clay that was deposited by the base of the ice during its advance in the Weichsel glaciation period. The dominant soil type is loamy sandy soils (40\%) and sandy clay soils (36\%). Average annual precipitation amounts to $740 \mathrm{~mm}$. The land use is dominated by arable land occupying $71 \%$ of the total area, followed by forested land $(15 \%)$ and urban areas $(8 \%)$. The population density in the catchment amounts to 124 inhabitants $\mathrm{km}^{-2}$. The total length of stream channels in the catchment amounts to $352 \mathrm{~km}$, equaling a stream density of $0.72 \mathrm{~km} \mathrm{~km}^{-2}$. The altitude range within the catchment is 12 to $127 \mathrm{~m}$, and all stream channels are therefore of the lowland stream type. The

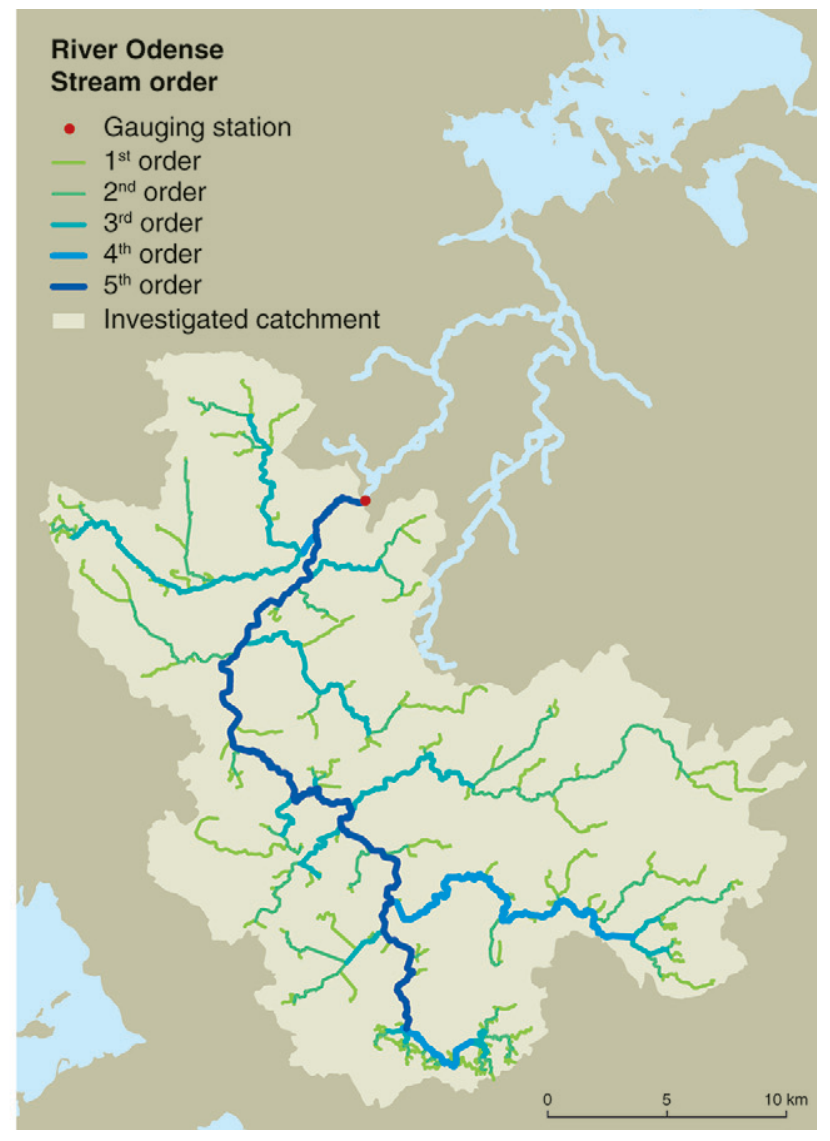

Fig. 1. The River Odense catchment on the island of Funen, Denmark, with a map (left) showing regulated and natural watercourses and the 36 sites for installation of erosion pins and a map (right) showing different stream orders and the gauging station installed at the catchment outlet. Inset map shows the location in Denmark. 
average slope of the 36 watercourses involved in the study was $2.02 \mathrm{~m} \mathrm{~km}^{-1}$ (range: $0.01-7.29 \mathrm{~m} \mathrm{~km}^{-1}$ ). In Denmark, uncultivated 2-m buffer strips along all natural watercourses and artificial watercourses having a high ecological objective were established in the Watercourse Act from 1991. Therefore, the watercourses involved in this study had at least a 2-m-wide buffer strip.

\section{Experimental Design}

A random stratified selection of different combinations of watercourse and buffer strip types were applied in the study. A preselection of different stream and buffer strip types were chosen for the field measurements of bank erosion. The reason behind the different types selected was to evaluate the importance of reinstating wider buffer zones along water courses in Denmark (e.g., $10-\mathrm{m}$ uncultivated buffers), as an important part of the Danish policy measures in Action Plan III for the Aquatic Environment for reducing nutrient loss to the aquatic environment was to allow for 50,000 ha of uncultivated $10-\mathrm{m}$ buffer zones along all 65,000-km stream types in Denmark (Kronvang et al., 2008). The different types selected were:

1. Artificially straightened watercourses vs. naturally meandering watercourses.

2. Stream orders: small—first and second orders; mediumthird and fourth orders; and large $-\geq$ fifth orders (Fig. 1).

3. Narrow uncultivated buffer strip $(\leq 2 \mathrm{~m})$ or wide uncultivated buffer strip ( $\geq 10 \mathrm{~m}$ ).

4. Low vegetation (grass or herbs) or high vegetation (trees and shrubs).

All combinations of types were represented in the experimental design except the combination of naturally meandering watercourses and narrow buffer strip, as these stream types always had a wide uncultivated buffer strip. A random, stratified selection of the 18 different combinations of stream and buffer zone types were conducted from a GIS analysis. A total of 10 watercourses, each $100 \mathrm{~m}$ long, were selected for each combination of types utilizing GIS maps. Finally, two replicate 100-mlong reaches of each combination of types, involving a total of 10 replicate plots, were randomly selected so a total of 36 stream reaches were included in the study design (Fig. 1). One of the selected reaches was, however, not measured due to active restoration of the stream channels during late autumn 2006.

\section{Measurements of Bank Retreat and Accretion}

Bank erosion was measured as bank retreat, utilizing $60-\mathrm{cm}$ long and 2-mm-diameter steel pins inserted at different heights into the banks during September 2006 (Fig. 2). Erosion pins have been widely used as a method for quantifying bank retreat and bank erosion processes (Lawler et al., 1999; Laubel et al., 2003; Zaimes et al., 2008). Each 100-m experimental stream reach consisted of five erosion pin plots, each consisting of three vertical lines of pins with a distance of $0.5 \mathrm{~m}$ between the lines (Fig. 2). In total, 3000 erosion pins were installed into 180 erosion pin plots by pushing them into the bank perpendicular to the bank face, leaving 40 to $60 \mathrm{~mm}$ exposed for ease of future location. Positive (erosion) and negative (accretion) pin readings were recorded within each pin plot in early spring during

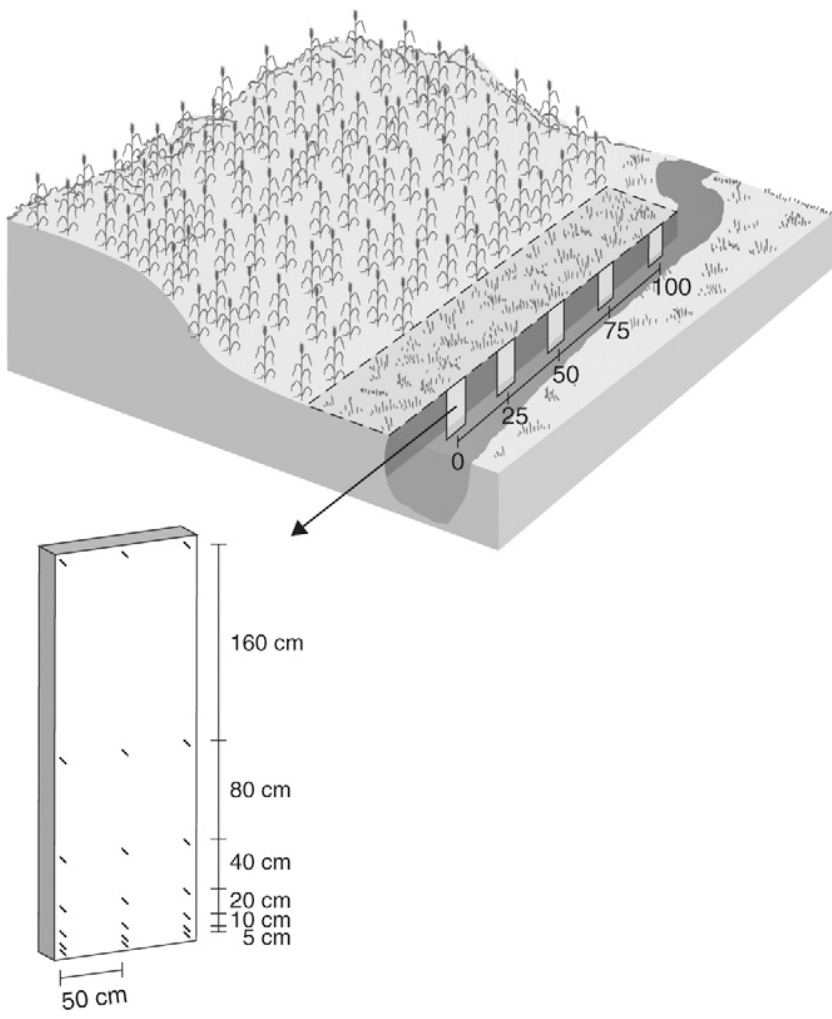

Fig. 2. The experimental setup along a $100-\mathrm{m}$ study reach having five erosion pin plots, each having three vertical lines of erosion pins situated at different heights above the streambed.

the three study years: 2006 to 2007, 2007 to 2008, and 2008 to 2009. Previous studies of bank erosion in first- and secondorder streams in Denmark have shown that erosion mainly takes place during the wet winter period where the banks are least protected by vegetation cover (Hasholt, 1988; Laubel et al., 2003). All pin readings were conducted with a metering stick and done by the same operator during all study years. Triplicate readings of bank retreat were done for each of a total of 96 pins placed in six different erosion pin plots to determine the uncertainty of the pin readings. The standard deviation of the three readings for each pin was calculated together with the average standard deviation. The result was an average standard deviation of $1.6 \mathrm{~mm}$, giving an uncertainty of $\pm 2 \mathrm{~mm}$ on the reading of erosion pins, which is a high resolution compared to that reported in other studies (Simon et al., 1999; Zaimes et al., 2008).

\section{Survey and Grouping of Plant Communities in Buffer Strip Plots}

The vegetation in the buffer strip is important for bank retreat processes, as their roots can stabilize the bank material. Therefore, the plant community was characterized within each of the 180 bank plots. A 1-by-1-m frame was placed at the edge of the stream channel, extending $1 \mathrm{~m}$ into the buffer strip. All species within the frame were identified to species level using the following abundance scale: $1:<1 \%, 2: 1$ to $5 \%, 3: 5$ to $10 \%, 4: 10$ to $25 \%, 5: 25$ to $50 \%, 6: 50$ to $75 \%, 7:>75 \%$. To analyze possible linkages between plant communities and bank erosion, a hierarchical clustering was performed using the Sorensen distance measure (PC-ORD 4.25, MjM Software, 
Gleneden Beach, OR). Plots with fewer than three species were omitted from this analysis to achieve a robust interpretation of the data. A total of six distinct plant communities (C1-C6) were identified, but C6 was represented by only five plots and was therefore excluded from further analysis.

Weighted means of Ellenberg $\mathrm{N}$ and Ellenberg L were calculated for the investigated plots (Ellenberg et al., 1992). The Ellenberg values range from 1 to 9 (9 being high) and reflect the preferences that the species exhibit for nutrients (Ellenberg $\mathrm{N}$ ) and light (Ellenberg L), respectively. Low values indicate preference for low amount of nutrients and light, whereas high values indicate preference for high amounts of nutrients and light.

\section{Laboratory Analysis}

Composite samples of bank material were collected from each $100-\mathrm{m}$ stream reach in spring of 2007. One sample of bank material was collected from $20 \mathrm{~cm}$ above the streambed, and another bank sample taken at $60 \mathrm{~cm}$ above the streambed. Core sampling was conducted within each of the five erosion pin plots, taking three subsamples within each plot to a depth of 5 $\mathrm{cm}$. Bank material bulk density was measured on $105^{\circ} \mathrm{C}$-dried material taken as composite core samples on each of the study reaches. Bank material from each of the 36 reaches was analyzed for total P content by the method described in Svendsen and Kronvang (1993).

The composition of particulate $\mathrm{P}$ forms in bank material and river suspended matter (see sampling procedure below) was analyzed by a five-step sequential extraction protocol (Psenner et al., 1984; Paludan and Jensen, 1995), where first loosely adsorbed $\mathrm{P}$ and iron-bound $\mathrm{P}$ is removed by 1 -h extraction in deionized water and in a solution of $0.11 \mathrm{M}$ bicarbonate/0.11 M dithionite, respectively. Afterward, leachable organic $\mathrm{P}$, humic-bound $\mathrm{P}$, and $\mathrm{P}$ adsorbed to aluminum oxides and clay was removed by an 18 -h extraction in $0.1 \mathrm{M} \mathrm{NaOH}$. The two final steps remove first calcium-bound $\mathrm{P}$ in $0.5 \mathrm{M}$ $\mathrm{HCl}$ and second, after combustion of the sediment residue, recalcitrant organic $\mathrm{P}$ by boiling in $1 \mathrm{M} \mathrm{HCl}$. Loosely adsorbed $\mathrm{P}$, iron-bound $\mathrm{P}$, and leachable organic $\mathrm{P}$ are considered available for algae growth under the conditions that prevail in streams, lakes, and estuaries (for discussion of bioavailability, see Egemose and Jensen, 2009).

\section{Statistical Methods}

Mean annual stream bank erosion rates (positive pin readings) and accretion rates (negative pin readings) were calculated from the pin readings within each pin plot. The absolute pin readings were natural log-transformed before averaging due to the right-skewed distribution (geometric mean). Mean bank erosion values per pin plot were back-transformed to the original scale by using the formula: $\exp ($ mean $) \times \exp (0.5 \times S D \times 2)$.

Mean annual stream bank erosion rates in the River Odense for all plots and for different stream types and buffer strip types were calculated from the back-transformed mean bank erosion on the plot scale. The mean values are given as $\mathrm{mm}$ $\mathrm{yr}^{-1}$ together with the standard error of the mean (arithmetic mean). Testing for differences in mean rates between stream types and buffer strip types was done by applying pair-wise tests using Bonferroni correction for dependent tests. Statistical tests were done on bank erosion data from plots transformed by natural logarithm due to the right-skewed distribution (geometric mean). Data were accepted to be Gaussian distributed after transformation using the Shapiro-Wilk test (Shapiro and Wilk, 1965), and variances were homogenous using Bartlett's test (Snedecor and Cochran, 1989).

\section{Calculation of Gross and Net Sediment and Phosphorus Loss}

Annual gross sediment delivery to the streams was calculated based on the geometric average of measured bank erosion rates from positive pin readings $\left(\mathrm{mm} \mathrm{yr}^{-1}\right)$ multiplied by the plot area and the bank material bulk density. Average annual rates of gross bank erosion (in $\mathrm{kg} \mathrm{km}^{-1}$ of stream) for the 18 categories of reaches (i.e., combinations of stream type, Strahler stream order, height of vegetation, and width of buffer zone) were then calculated utilizing the 10 erosion pin plots for each stream type. The total channel length of each stream type in the River Odense catchment was calculated from GIS maps and aerial photographs (Table 1). The length of each stream type was then multiplied with the calculated average annual gross bank erosion of sediment per kilometer of stream.

The average concentration of total $P$ in stream bank material for each stream type was multiplied by the gross sediment loss to yield an annual gross total P load derived from bank erosion to the stream channels within the River Odense catchment. The net sediment export from the River Odense catchment was calculated by subtracting the amount of accretion of sediment per stream type extrapolated to the entire catchment from the calculated gross sediment input from bank erosion to the entire River Odense catchment. Similarly, the net total P export from the River Odense catchment from bank erosion was calculated by subtracting the total $\mathrm{P}$ content in deposited sediment (200-400 mg P kg-1 dry weight [DW]) from the gross total $\mathrm{P}$ input from bank erosion.

\section{Measurements of Discharge and Phosphorus Export}

Daily mean discharge was calculated for the study period (2006-2009) based on stage-discharge relationships developed for a long-term (1917) hydrometric station at Kratholm in the River Odense. Instantaneous discharge was measured every month, and water sampling was conducted with a combination of automatic sampling equipment (daily sampling) and grab sampling (fortnightly). The export of total P from the River Odense catchment was calculated from a linear interpolation of daily concentrations being multiplied with daily discharge as described by

Table 1. Stream length for the different categories of stream type and Strahler order.

\begin{tabular}{lcc}
\hline \multicolumn{1}{c}{ Stream type } & Strahler order & Length \\
\hline \multirow{3}{*}{ Natural } & & $\mathrm{km}$ \\
& $1-2$ & 19.3 \\
& $3-4$ & 24.9 \\
Regulated & 5 & 11.6 \\
& $1-2$ & 208.5 \\
& $3-4$ & 59.6 \\
& 5 & 26.5 \\
\hline
\end{tabular}


Kronvang and Bruhn (1996). The precision associated with this $\mathrm{P}$ load calculation method will depend on the frequency of water sampling but is often within \pm 10 to $15 \%$ when having fortnightly water sampling in a catchment of the size of the River Odense (Kronvang and Bruhn, 1996). Source apportionment for calculation of the $\mathrm{P}$ loss from diffuse sources was conducted by extracting point source discharges of $\mathrm{P}$ within the catchment from the measured export of total $\mathrm{P}$ at the Kratholm river station as described by Kronvang et al. (2005). Suspended sediment samples were collected at the Kratholm station in the River Odense on a nearly monthly basis during the first study year by deploying an in situ passive sediment sampler described by Laubel et al. (2002). Samples for total P were dried $\left(105^{\circ} \mathrm{C}, 24 \mathrm{~h}\right)$, while samples for P-pool distribution were kept cold $\left(<5^{\circ} \mathrm{C}\right)$ and oxic until analysis (within 1 mo from sampling).

\section{Results}

\section{Plant Communities in Buffer Strips}

A total of five distinct plant communities (C1-C5) were identified in the investigated buffer strip plots. Cluster 1 was represented in 30 plots, Cluster 2 in 14 plots, Cluster 3 in 35 plots, Cluster 4 in 65 plots, and Cluster 5 in 18 plots. The most abundant species within each of the identified clusters is given in Table 2 . The species richness was not significantly different among clusters (ANOVA $p>0.05$ ), whereas Ellenberg $\mathrm{N}$ and Ellenberg $\mathrm{L}$ were significantly different (ANOVA $p$ $<0.05$ ). Ellenberg $\mathrm{N}$ was significantly lower in Clusters 1 (average 6.7) and 2 (average 5.5) than in Clusters 3 (average 7.1), 4 (average 7.0), and 5 (average 7.1; Bonferroni $t$ test, $p<0.05)$. Similarly, Ellenberg L was significantly lower in Clusters 1 (average 5.4) and 2 (average 5.1) than in Clusters 3 (average 6.4), 4 (average 6.6), and 5 (average 6.7; Bonferroni $t$ test, $p<0.05)$.

\section{Quantifying Bank Erosion along Different Stream and Buffer Strip Types}

Average annual bank erosion rates in 175 erosion pin plots ranged between 25 and $36 \mathrm{~mm} \mathrm{yr}^{-1}$ during the 3 -yr study period (Table 3). The observed median annual bank erosion rates indicated a relationship to the water flow from the catchment being highest during the wet Year 1 (2006-2007) and lowest in the dry Year 2 (2008-2009).

The 18 different combinations of stream channel and buffer strip types together with information on plant communities were statistically tested for differences in annual average bank erosion per plot by applying pair-wise tests using Bonferroni correction for dependent tests. The hypothesis that stream channels with narrow uncultivated buffer strips $(\leq 2 \mathrm{~m})$ had higher bank erosion rates than stream channels having a wide uncultivated buffer strip $(\geq 10 \mathrm{~m})$ could not be accepted statistically, as no significant $(p<0.05)$ differences were detected (Tables 4 and 5). Bank erosion rates were not statistically different between the three groups of stream orders $(p<0.05)$, nor could a statistically significant difference be obtained between straightened and naturally meandering stream channels (Table 4). Significant differences $(p<0.05)$ in bank erosion rates were found between stream channels with buffer strips of different vegetation types (high or low) and plant community types (Table 5).

\section{Annual Gross and Net Phosphorus Input to Surface Waters from Bank Erosion}

The total $\mathrm{P}$ content was relatively high in bank material, averaging $712 \mathrm{mg} \mathrm{P} \mathrm{kg}^{-1} \mathrm{DW}$ at $20 \mathrm{~cm}$ above the streambed and $723 \mathrm{mg} \mathrm{P} \mathrm{kg}{ }^{-1} \mathrm{DW}$ at $60 \mathrm{~cm}$ above the streambed (Fig. 3). The total $\mathrm{P}$ content of bank material was not significantly different $(p=0.67)$ between the two heights above the streambed where soil samples were taken. The distribution of $\mathrm{P}$ forms in the bank material was analyzed in seven composite samples

Table 2. The relative abundance of the five most abundant species in the identified clusters.

\begin{tabular}{|c|c|c|c|c|c|c|c|c|c|}
\hline \multicolumn{2}{|l|}{ Cluster 1} & \multicolumn{2}{|l|}{ Cluster 2} & \multicolumn{2}{|l|}{ Cluster 3} & \multicolumn{2}{|l|}{ Cluster 4} & \multicolumn{2}{|l|}{ Cluster 5} \\
\hline Species & $\%$ & Species & $\%$ & Species & $\%$ & Species & $\%$ & Species & $\%$ \\
\hline Mercurialis perennis L. & 13.6 & Agrostis capillaries L. & 16.1 & Urtica dioica $\mathrm{L}$. & 14.1 & $\begin{array}{l}\text { Arrhenatherum elatius } \\
\text { (L.) J. Presl \& C. Presl }\end{array}$ & 15.3 & $\begin{array}{l}\text { Alopecurus pratensis } \\
\mathrm{L} .\end{array}$ & 32.5 \\
\hline $\begin{array}{l}\text { Petasites hybridus (L.) } \\
\text { P. Gaertn., B. Mey. \& } \\
\text { Scherb. }\end{array}$ & 7.8 & $\begin{array}{l}\text { Galium odoratum (L.) } \\
\text { Scop. }\end{array}$ & 12.1 & $\begin{array}{l}\text { Aegopodium } \\
\text { podagraria } \mathrm{L} .\end{array}$ & 13.1 & Urtica dioica L. & 14.9 & Urtica dioica L. & 12.2 \\
\hline $\begin{array}{l}\text { Aegopodium podagraria } \\
\text { L. }\end{array}$ & 7.5 & Acer platanoides L. & 10.5 & Galium aparine L. & 10.8 & Poa trivialis L. & 12.1 & $\begin{array}{l}\text { Phalaris arundinacea } \\
\text { L. }\end{array}$ & 8.6 \\
\hline Urtica dioica L. & 7.1 & $\begin{array}{c}\text { Melampyrum } \\
\text { pratense } \mathrm{L} .\end{array}$ & 7.3 & Poa trivialis L. & 9.9 & $\begin{array}{l}\text { Elytrigia repens (L.) } \\
\text { Nevski }\end{array}$ & 8.5 & $\begin{array}{l}\text { Calystegia sepium } \\
\text { (L.) R. Br. }\end{array}$ & 7.6 \\
\hline Galium aparine L. & 5.8 & Galium aparine L. & 4.0 & $\begin{array}{l}\text { Petasites hybridus (L.) } \\
\text { P. Gaertn., B. Mey. \& } \\
\text { Scherb. }\end{array}$ & 8.3 & Galium aparine L. & 7.1 & Galium aparine L. & 7.6 \\
\hline
\end{tabular}

Table 3. Average gross annual and median annual bank erosion in the River Odense catchment as measured from positive pin readings in 175 erosion pin plots compared with annual (October-September) and winter (October-March) runoff from the catchment at the Kratholm hydrometric station.

\begin{tabular}{lccr}
\hline \multicolumn{1}{c}{ Erosion and runoff } & Year 1 & Year 2 & Year 3 \\
\hline Average bank erosion $(\mathrm{mm})$ & 36 & 25 & 26 \\
Median bank erosion $(\mathrm{mm})$ & 27 & 16 & 16 \\
Annual runoff $(\mathrm{mm})$ & 450 & 302 & 186 \\
Winter runoff $(\mathrm{mm})$ & 313 & 229 & 139 \\
\hline
\end{tabular}


Table 4. Bank erosion at two different stream types regarding stream order and degree of channel modification. Calculations are based on data from erosion plots.

\begin{tabular}{|c|c|c|c|c|c|c|c|c|}
\hline \multirow{2}{*}{ Stream type } & \multicolumn{8}{|c|}{ Streambank erosion rate† } \\
\hline & Year 1 & $\operatorname{SEM}(n)$ & Year 2 & $\operatorname{SEM}(n)$ & Year 3 & $\operatorname{SEM}(n)$ & Avg. year 1-3 & $\operatorname{SEM}(n)$ \\
\hline & & & & 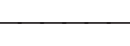 & $\mathrm{yr}^{-1}-$ & & & - \\
\hline \multicolumn{9}{|l|}{ Stream size } \\
\hline First- and second-order streams & $30 a \neq$ & $2.7(59)$ & $19 a$ & $1.5(60)$ & $23 a$ & $3.7(60)$ & $24 a$ & $1.6(179)$ \\
\hline Third- and fourth-order streams & $38 a$ & $6.0(58)$ & $25 a$ & $4.9(54)$ & $31 a$ & $4.8(49)$ & $31 a$ & $3.1(161)$ \\
\hline Fifth-order streams & $46 a$ & $8.7(51)$ & $42 a$ & $11(52)$ & $32 a$ & $6.9(53)$ & $40 a$ & $5.2(156)$ \\
\hline \multicolumn{9}{|l|}{ Degree of channel modification } \\
\hline Channelized streams & $34 a$ & $4.2(113)$ & $25 a$ & $3.8(109)$ & $30 a$ & $4.1(105)$ & $30 a$ & $2.3(327)$ \\
\hline Natural streams & $45 a$ & $6.3(55)$ & $33 a$ & $8.6(57)$ & $25 a$ & $4.2(57)$ & $34 a$ & $3.9(169)$ \\
\hline
\end{tabular}

† Year 1: 2006-2007, Year 2: 2007-2008, Year 3: 2008-2009; $n$ : number of observations.

₹ Different letters $(\mathrm{a}, \mathrm{b}, \mathrm{c})$ indicate significant differences $(p<0.05)$ among different stream types within the two groups tested.

Table 5. Bank erosion at three different buffer strip types regarding width of uncultivated buffer strip, high or low vegetation in buffer strip, and buffer strip plant types. Calculations based on data from erosion plots.

\begin{tabular}{|c|c|c|c|c|c|c|c|c|}
\hline \multirow{2}{*}{ Stream type } & \multicolumn{8}{|c|}{ Streambank erosion rate $\dagger$} \\
\hline & Year 1 & $\operatorname{SEM}(n)$ & Year 2 & $\operatorname{SEM}(n)$ & Year 3 & $\operatorname{SEM}(n)$ & Avg. year 1-3 & $\operatorname{SEM}(n)$ \\
\hline & & & & 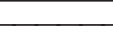 & $\mathrm{yr}^{-1}$ & & & - \\
\hline \multicolumn{9}{|l|}{ Buffer strip width } \\
\hline Streams with narrow buffer strips & $26 a \neq$ & $2.1(53)$ & $15 a$ & $1.0(50)$ & $27 a$ & $4.6(45)$ & $22 a$ & $1.7(148)$ \\
\hline Streams with wide buffer strips & $41 a$ & $7.6(60)$ & $35 a$ & $6.8(59)$ & $32 \mathrm{a}$ & $6.2(60)$ & $36 a$ & $4.0(179)$ \\
\hline \multicolumn{9}{|l|}{ Buffer strip vegetation height } \\
\hline Streams with high vegetation & $30 a$ & $4.1(85)$ & $24 a$ & $5.7(87)$ & $21 a$ & $3.2(84)$ & $25 a$ & $2.6(256)$ \\
\hline Streams with low vegetation & $46 b$ & $5.6(83)$ & $33 b$ & $5.2(79)$ & $36 b$ & $5.2(78)$ & $38 \mathrm{~b}$ & $3.1(240)$ \\
\hline \multicolumn{9}{|l|}{ Buffer strip plant types } \\
\hline Streams with Plant Type 1 & $25 a b$ & $2.9(30)$ & $18 \mathrm{ab}$ & $2.5(30)$ & $17 a b$ & $4.6(30)$ & $20 \mathrm{~b}$ & $2.0(90)$ \\
\hline Streams with Plant Type 2 & $16 a$ & $2.6(14)$ & $8.2 \mathrm{a}$ & $1.1(14)$ & 7.6a & $0.90(14)$ & $11 a$ & $1.1(42)$ \\
\hline Streams with Plant Type 3 & $42 a b c$ & $11(29)$ & $38 \mathrm{ab}$ & $16(29)$ & $27 \mathrm{bc}$ & $6.6(27)$ & $36 \mathrm{bc}$ & $7.0(85)$ \\
\hline Streams with Plant Type 4 & $47 c$ & $6.9(64)$ & $31 b$ & $5.5(64)$ & $33 \mathrm{bc}$ & $6.0(62)$ & $37 c$ & $3.6(190)$ \\
\hline Streams with Plant Type 5 & $41 \mathrm{bc}$ & $8.7(18)$ & $39 \mathrm{~b}$ & $12(16)$ & $40 c$ & $7.4(17)$ & $40 c$ & $5.4(51)$ \\
\hline
\end{tabular}

+ Year 1: 2006-2007, Year 2: 2007-2008, Year 3: 2008-2009; $n$ : number of observations.

₹ Different letters $(a, b, c, a b, a c, a b c)$ indicate significant differences $(p<0.05)$ among the three different tested buffer strip types.

(representing different sampling dates and with an average $\mathrm{P}$ content of $775 \mathrm{mg} \mathrm{kg}^{-1} \mathrm{DW}$; data not shown). Iron-bound P contributed $>50 \%$ to the total pool in all samples and the dis-

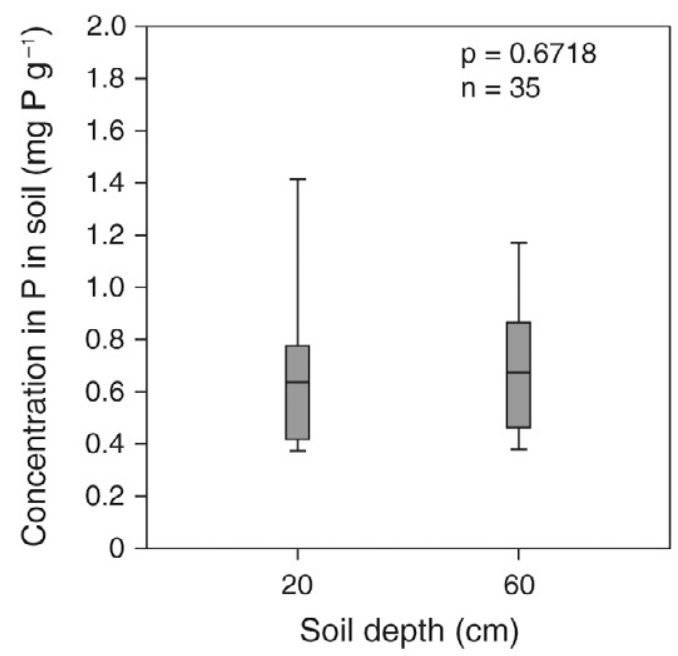

Fig. 3. The total phosphorus content of stream bank material analyzed from 35 composite bank material samples taken at two heights above the streambed $(20$ and $60 \mathrm{~cm})$, shown as the median content and the $5,25,75$, and $95 \%$ percentiles. tribution of forms resembled that found in suspended sediment (Fig. 4; also see below).

The gross amount of $\mathrm{P}$ mobilized with bank erosion from the 18 different combinations of stream and buffer strip types is shown in Table 6 for all three study years. The gross P mobilization varied between stream types with a minimum annual mobilization amounting to $4.2 \mathrm{~kg} \mathrm{P} \mathrm{km}^{-1}$ stream channel and a maximum mobilization amounting to $167.0 \mathrm{~kg} \mathrm{P} \mathrm{km}^{-1}$ stream channel (Table 6).

\section{Importance of Bank Erosion as Phosphorus Source at Catchment Scale}

The gross P mobilization from bank erosion in the entire River Odense catchment was compared to the net export of total $P$ from the catchment as measured at the monitoring station at the catchment outlet (Table 7). The gross $\mathrm{P}$ mobilization amounted to 13.8 to 16.5 t P during the three study years. Negative erosion pin readings show that part of the mobilized sediment and $\mathrm{P}$ are retained in the stream channels during the study period. The net $\mathrm{P}$ mobilization from bank erosion in the River Odense catchment amounted to 17 to $25 \%$ of the total $\mathrm{P}$ export from catchment during the three study years when $\mathrm{P}$ content in retained sediment was considered to be between 
200 and $400 \mathrm{mg} \mathrm{P} \mathrm{kg}^{-1} \mathrm{DW}$ (Table 6). The importance of bank erosion as a diffuse $\mathrm{P}$ source shows that in the wet study year (2006-2007) 21 to $23 \%$ of the diffuse P loss can be attributed to bank erosion and in a dry year (2008-2009) 44 to $62 \%$ of the diffuse $\mathrm{P}$ loss is derived from bank erosion (Table 7).

The suspended sediment had a P concentration four times higher (average $3410 \mathrm{mg} \mathrm{P} \mathrm{kg}^{-1} \mathrm{DW}$ ) than the bank sediment, but the distribution of $\mathrm{P}$ forms was very similar to that in bank sediment and did not vary much with season (Fig. 4). Most of the exported $\mathrm{P}$ in suspended sediment was bound to iron complexes (average: 59\%), easily decomposable organic matter (11\%), and loosely adsorbed P (1.7\%), forms that are considered bioavailable (Fig. 4).

\section{Discussion and Conclusions}

The overall mean annual bank erosion rates observed in this study $\left(31 \mathrm{~mm} \mathrm{yr}^{-1}\right)$ were nearly three times higher than in a previous study of bank erosion in 15 Danish channelized firstand second-order stream banks $\left(11 \mathrm{~mm} \mathrm{yr}^{-1}\right.$ ) (Laubel et al., 2003). This study included several higher-order streams, but our findings of mean bank erosion in channelized first- and second-order streams with same bank height were still higher $\left(24 \mathrm{~mm} \mathrm{yr}^{-1}\right)$ than in the study by Laubel et al. (2003). One possible reason is that during this study we applied thin steel pins without a reference square of hard plastic pressed toward the banks ( 4.5 by $4.5 \mathrm{~cm}$ ) that might have protected the banks from hydraulic erosion processes in the study by Laubel et al. (2003). The range found for mean bank erosion rates is, however, considerably lower than that observed in the bank erosion studies by Hooke (1980) and Lawler (1993), but in the same range as the findings by Bull (1997) in the River Severn in Wales and by Couper (2003) studying the influence of subareal activity on bank erosion in River Avon in England.

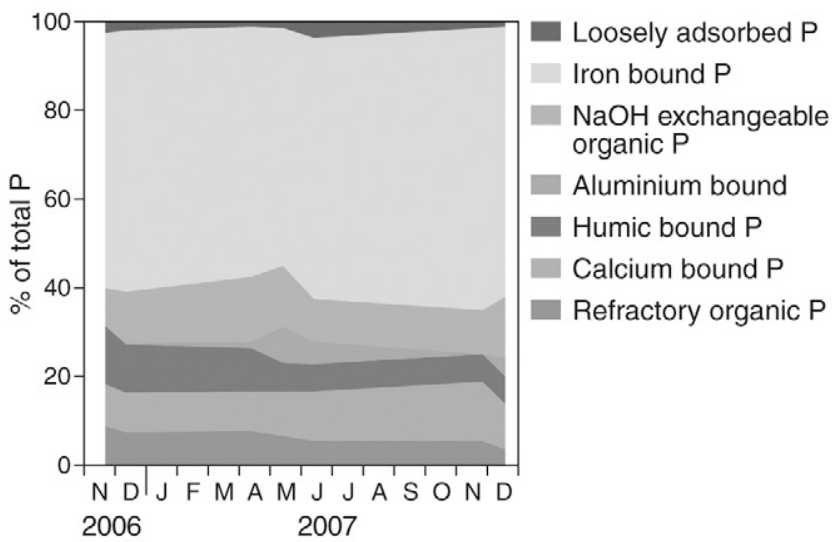

Fig. 4. Composition of particulate $P$ forms in suspended sediment trapped in River Odense through year 2007. The P forms were analyzed by chemical sequential extraction. The first three forms, contributing $>70 \%$ of total $P$, are considered bioavailable.

Stream bank erosion rates were found to be influenced by riparian land use in a 3-yr study of streams in Iowa, USA (Zaimes et al., 2008). The mean bank erosion rates were 15 to $46 \mathrm{~mm} \mathrm{yr}^{-1}$ along riparian forest buffers, 41 to $106 \mathrm{~mm} \mathrm{yr}^{-1}$ along grass filters, 104 to $122 \mathrm{~mm} \mathrm{yr}^{-1}$ along rotational pastures, and highest along row-cropped fields 223 to $271 \mathrm{~mm} \mathrm{yr}^{-1}$ (Zaimes et al., 2008). These results are generally much higher than our overall mean annual bank erosion results of $31 \mathrm{~mm}$ $\mathrm{yr}^{-1}$. This might be due to difference in experimental design, as we applied a random selection of study reaches, whereas the study by Zaimes et al. (2008) only depicted severely eroding bare stream banks in their study based on a preliminary field survey. The relatively short study period ( 3 yr) means that major bank collapses that might occur with longer time intervals may not be systematically recorded with the erosion pin method

Table 6. Gross total P mobilized by bank erosion in River Odense catchment, Denmark. The stream network was stratified using GIS tools to obtain classification of streams according to their type (natural or regulated), Strahler order, height of vegetation (high: trees and shrubs; low: grass and herbs) and width of the buffer zone (wide $\geq 10 \mathrm{~m}$ and narrow $\leq 2 \mathrm{~m}$ ).

\begin{tabular}{|c|c|c|c|c|c|c|}
\hline \multirow{2}{*}{ Stream type } & \multirow{2}{*}{ Strahler order } & \multirow{2}{*}{ Vegetation height } & \multirow{2}{*}{ Buffer zone width } & \multicolumn{3}{|c|}{ P mobilized } \\
\hline & & & & $2006-2007$ & $2007-2008$ & 2008-2009 \\
\hline & & & & \multicolumn{3}{|c|}{$\mathrm{kg} \mathrm{km}^{-1} \longrightarrow$} \\
\hline Natural & $1-2$ & High & $\dagger$ & 14.3 & 11.9 & 5.8 \\
\hline Natural & $1-2$ & Low & $\dagger$ & 35.0 & 20.1 & 28.0 \\
\hline Natural & $3-4$ & High & $\dagger$ & 44.0 & 34.7 & 19.6 \\
\hline Natural & $3-4$ & Low & $\dagger$ & 59.0 & 29.4 & 30.5 \\
\hline Natural & 5 & High & $\dagger$ & 19.4 & 15.4 & 21.8 \\
\hline Natural & 5 & Low & + & 55.8 & 23.6 & 12.4 \\
\hline Regulated & $1-2$ & High & Wide & 12.1 & 10.5 & 4.2 \\
\hline Regulated & $1-2$ & Low & Wide & 10.5 & 9.4 & 12.3 \\
\hline Regulated & $3-4$ & High & Wide & 8.6 & 7.9 & 7.9 \\
\hline Regulated & $3-4$ & Low & Wide & 18.9 & 32.5 & 44.1 \\
\hline Regulated & 5 & High & Wide & 29.7 & 31.0 & 15.5 \\
\hline Regulated & 5 & Low & Wide & 167.0 & 106.9 & 80.3 \\
\hline Regulated & $1-2$ & High & Narrow & 15.9 & 18.5 & 80.1 \\
\hline Regulated & $1-2$ & Low & Narrow & 22.8 & 17.6 & 11.0 \\
\hline Regulated & $3-4$ & High & Narrow & 8.6 & 4.9 & 8.0 \\
\hline Regulated & $3-4$ & Low & Narrow & 22.2 & 14.7 & 12.7 \\
\hline Regulated & 5 & High & Narrow & 49.6 & 28.1 & 20.1 \\
\hline Regulated & 5 & Low & Narrow & 31.8 & 25.9 & 29.3 \\
\hline
\end{tabular}

† All natural streams had a vegetated buffer zone $>10 \mathrm{~m}$. 
utilized during this study. This might be another reason for the large difference between the observations of bank retreat in this study and the observations of bank erosion also conducted during 3 yr by Zaimes et al. (2008).

Our findings of the reduced stream bank erosion in banks with natural vegetation as indicated by occurrence of tree vegetation and forest floor communities with low preferences for nutrients and light is corroborated by the findings of reduced bank erosion in riparian forest buffers by Zaimes et al. (2008) and forested stream banks in the study by Laubel et al. (1999). Several other authors have given evidence from longer-term studies of bank erosion that land-use changes may affect slope stability and bank erosion (Hagerty et al., 1981; Brierley and Murn, 1997; Abernethy and Rutherfurd, 1998).

The importance of bank erosion as a source of $\mathrm{P}$ has seldom been documented, especially in catchment budgets. Zaimes et al. (2008) investigated the amount of P mobilization from stream banks along different riparian land use in Iowa, USA. They found $\mathrm{P}$ losses between 2 and $6 \mathrm{~kg} \mathrm{P} \mathrm{km}^{-1} \mathrm{yr}^{-1}$ being lowest from riparian forests $\left(2-6 \mathrm{~kg} \mathrm{P} \mathrm{km}^{-1} \mathrm{yr}^{-1}\right)$ and highest from continuous riparian land use (71-123 $\mathrm{kg} \mathrm{P} \mathrm{km}^{-1} \mathrm{yr}^{-1}$ ) (Zaimes et al., 2008). Laubel et al. (2003) found an annual P loss from bank erosion of 0.23 to $0.28 \mathrm{~kg} \mathrm{P} \mathrm{ha}^{-1}$ catchment area in their study of 15 first- and second-order agricultural catchments and, having approximately $1 \mathrm{~km}$ of stream channel per square kilometer of catchment area as in this study, these findings amount to 23 to $28 \mathrm{~kg} \mathrm{P} \mathrm{km}^{-1} \mathrm{yr}^{-1}$. The findings in this study show a total P loss from gross bank erosion that amounts to 4.2 to $167.0 \mathrm{~kg} \mathrm{P} \mathrm{km}^{-1} \mathrm{yr}^{-1}$ depending on year and type of stream and buffer zone (Table 5). The P loss from bank erosion in this study is thus comparable to the level found by Zaimes et al. (2008). Similarly, our findings of a gross P loss from bank erosion of 0.28 to $0.34 \mathrm{~kg} \mathrm{P} \mathrm{ha}^{-1}$ catchment area is at a similar level as the findings of Laubel et al. (2003).

In this study we investigated for the first time the net outcome of the bank erosion processes and the fluvial depositional processes. The positive (erosion) and negative (accretion) erosion pin readings made it possible to calculate a net contribution of $\mathrm{P}$ from bank erosion subtracting $\mathrm{P}$ sedimentation in the stream channels from the gross $\mathrm{P}$ input. Net $\mathrm{P}$ input from bank erosion amounted on average to 20 to $36 \%$ of the gross $\mathrm{P}$ input during the three study years. The difference in total $\mathrm{P}$ content between suspended sediment (average $3410 \mathrm{mg} \mathrm{P} \mathrm{kg}^{-1}$ DW) and bank sediment (712-723 mg $\left.\mathrm{P} \mathrm{kg}^{-1} \mathrm{DW}\right)$ is likely because bank sediment contains high proportions of sand-sized material having a very low P content, whereas suspended sediment often has high proportions of silt and clay-sized material being enriched in $\mathrm{P}$.
Only a smaller part of the gross $\mathrm{P}$ input with soil material thereby seems to leave the catchment during the same year. This finding is in accordance with the findings of Collins and Walling (2007) in two study catchments in the United Kingdom (Tern and Pang/Lambourn) where fine sediment storage was found to represent a significant term in catchment sediment budgets. Storage of fine sediment with a high P content in river channels is, therefore, an important process influencing the resulting export from the catchment during extreme flow events together with instream processing of sediment and $\mathrm{P}$ (e.g., uptake of $\mathrm{P}$ in macrophyte biomass) that might remove both fine sediment and P from the stream system through weed cutting and following the removal of the dead plant biomass.

The net P input was highest during the wet year of 20062007 (36\%) and lowest during the driest year of 2008-2009, showing the importance of fluvial hydraulic processes in determining sediment and particulate $\mathrm{P}$ transfer through the river continuum (Kronvang et al., 1997; Walling et al., 1998). The deposited $\mathrm{P}$ in stream channels may be flushed downstream by later extreme events (spates) in discharge. Extreme rainfall episodes may, therefore, contribute to excess $P$ loads in catchments derived from a combination of excess bank erosion and the flushing downstream of P-enriched sediments, which might be a problem overlooked in previous scenarios on effects of climate change on P losses and impacts on eutrophication (Jeppesen et al., 2009). The importance for downstream recipients is stressed by the fact that $>70 \%$ of the particulate $\mathrm{P}$ in bank sediment (as well as in riverborne sediment) can be considered bioavailable and therefore potentially contributes to eutrophication.

Overbank phosphorus deposition in riparian areas is another important process that may influence net $\mathrm{P}$ fluxes through catchments (Kronvang et al., 2007, 2009b). Reconnection of inundated riparian areas to the fluvial system is popular as a mitigation measure for lowering nutrient loads in many countries (Hoffmann and Baattrup-Pedersen, 2007; Moss and Monstadt, 2008; Hoffmann et al., 2009; Kronvang et al., $2009 \mathrm{~b})$. Changes in the magnitude of bank erosion and storage processes in fluvial systems as well as their impact on phosphorus losses are expected to occur during the coming decades, caused especially by climate change but also by catchment management involving restoration of streams and wetlands. Increasing flooding inundation risks associated with climate change may also cause a risk for remobilization of $\mathrm{P}$ from the soil $\mathrm{P}$ pool and from deposited $\mathrm{P}$, depending on factors such as the iron/P ratio in soil and deposited sediments and the hydrology of the river and floodplain (Hoffmann et al., 2009).

Table 7. Gross and net P mobilization from bank erosion as compared to the export of total P in the River Odense catchment during three hydrological years (2006-2007, 2007-2008, and 2008-2009).

\begin{tabular}{|c|c|c|c|}
\hline Phosphorus mobilization and transport & 2006-2007 & 2007-2008 & 2008-2009 \\
\hline & \multicolumn{3}{|c|}{$\longrightarrow$ tonnes P } \\
\hline Gross P mobilization from bank erosion & 16.5 & 13.8 & 14.2 \\
\hline Net $\mathrm{P}$ mobilization from bank erosion & $5.6-6.3$ & $3.6-4.2$ & 2.4-3.4 \\
\hline Total P transport in River Odense at Kratholm station during hydrological years (Oct.-Sept.) & 33.4 & 21.5 & 11.6 \\
\hline Contribution from bank erosion to total transport (\%) & $17-19$ & $17-20$ & $21-29$ \\
\hline Total P loss from diffuse sources from the River Odense, Kratholm during hydrological years (Oct.-Sept.) & 27.3 & 15.4 & 5.5 \\
\hline Contribution of bank erosion to diffuse losses (\%) & $21-23$ & $23-27$ & $44-62$ \\
\hline
\end{tabular}


The net input of $\mathrm{P}$ from bank erosion amounted on average to 18 to $25 \%$ of the annual total $\mathrm{P}$ export from the River Odense catchment but 22 to $53 \%$ of the annual total P loss from diffuse sources in the catchment (Table 7). Therefore, our study proves bank erosion to be a highly important diffuse $\mathrm{P}$ source in lowland river basins. Fingerprinting studies tracing the origin of suspended sediment in catchments has proven bank erosion to be an important source in some studies (Owens et al., 2000; Walling et al., 1998), whereas in other cases tile drains (Russell et al., 2001) or topsoils contribute more suspended sediment than eroding banks (Collins et al., 1997).

We have demonstrated that during all seasons a large part of the exported $\mathrm{P}$ with suspended sediment from the catchment is or can be bioavailable when transported to downstream surface water systems like an estuary as is the case in the River Odense. Bank erosion-derived $\mathrm{P}$ is therefore also important as an eutrophication driver in surface waters. Few $\mathrm{P}$ models working at catchment scale include bank erosion as a diffuse P source (Schoumans et al., 2009; Kronvang et al., 2009a). The controls on cohesive river bank erosion and fluvial processes of sedimentation and resuspension is therefore a fundamental problem when modeling P sources and dynamics within catchments.

An important mitigation measure that might reduce the problem of bank erosion as a diffuse $\mathrm{P}$ source is to change land use along the riparian corridor from intensive agricultural production to grassland or riparian forest as proven by Zaimes et al. (2008). This study confirms that planting trees in buffer strips reduces bank erosion by as much as 25 to $40 \%$ compared to erosion rates from buffer strips planted with vegetation such as grass and herbs. The high P content of bank material found in this study $\left(718 \mathrm{mg} \mathrm{P} \mathrm{kg}^{-1}\right)$ may be derived from different sources related to agricultural activities (fertilization), inflow of reduced groundwater, maintenance processes in the stream channel (weed cutting and dredging), and inflow of stream water through the hyporheic zone. Active mining of $\mathrm{P}$ in the buffer strip through phytoremediation can therefore be a very important maintenance activity (Adler et al., 2008).

In summary, we can conclude the following from our measurements in the River Odense catchment, Denmark: (i) bank erosion is an important diffuse $\mathrm{P}$ source in lowland river systems, delivering 21 to $62 \%$ of the annual export of total $\mathrm{P}$ from diffuse sources; (ii) the dominant part of $\mathrm{P}$ in suspended sediment collected at the catchment outlet was measured to be bioavailable (71.7\%); (iii) bank erosion was measured to be significantly lower $(p<0.05)$ along buffer strips with high vegetation (natural trees and shrubs) than along buffer strips with low vegetation (grass and herbs) during all three study years; (iv) neither stream size nor stream disturbance (channelization) or width of an uncultivated buffer strip had any significant $(p<$ $0.05)$ influence on bank erosion and P loss during each of the three study years.

The outcome of this study is important for catchment managers working with implementation of mitigation measures, such as buffer strips, for reducing P losses to surface waters and for catchment modelers who need to include the importance of bank erosion as a diffuse P source when analyzing P sources and $\mathrm{P}$ loadings.

\section{Acknowledgments}

This work was presented during a workshop organized within COST Action 869 in Ballater, UK. The work was supported by the Neighbors and the Environment Research Programme project "BUFFALO-P" and the Strategic Research Foundation project 'MONITECH' (Grant No. 2104-08-0050). Henning S. Jensen received additional support from the Danish Council for Independent Research-Natural Sciences (Grant No. 09-071369) and from VKR Centre for Lake Restoration (CLEAR).

\section{References}

Abernethy, B., and I.D. Rutherfurd. 1998. Where along a river's length will vegetation most effectively stabilise stream banks? Geomorphology 23:55-75. doi:10.1016/S0169-555X(97)00089-5

Adler, A., A. Karacic, and M. Weih. 2008. Biomass allocation and nutrient use in fast-growing woody and herbaceous perennials used for phytoremediation. Plant Soil 305:189-206. doi:10.1007/s11104-008-9551-2

Brierley, G.J., and C.P. Murn. 1997. European impacts on downstream sediment transfer and bank erosion in Cobargo catchment, New South Wales, Australia. Catena 31:119-136. doi:10.1016/S0341-8162(97)00025-8

Bull, L.J. 1997. Magnitude and variation in the contribution of bank erosion to the suspended sediment load of the River Severn, UK. Earth Surf. Processes Landforms 22:109-1123.

Collins, A.L., and D.E. Walling 2007. Sources of fine sediment recovered from the stream bed of lowland groundwater-fed catchments in the UK. Geomorphology 88:120-138.

Collins, A.L., D.E. Walling, and G.J.L. Leeks. 1997. Sediment sources in the Upper Severn catchment: A fingerprinting approach. Hydrol. Earth Syst. Sci. 1:509-521. doi:10.5194/hess-1-509-1997

Collins, A.L., D.E. Walling, L. Webb, and P. King. 2010. Apportioning catchment scale sediment sources using a modified composite fingerprinting technique incorporating property weightings and prior information. Geoderma 155:249-261. doi:10.1016/j.geoderma.2009.12.008

Couper, P. 2003. Effects of silt-clay content on the susceptibility of river banks to subaerial erosion. Geomorphology 56:95-108. doi:10.1016/ S0169-555X(03)00048-5

Danish Ministry of Environment. 2010. Draft River Basin Management Plan—River Basin Randers 1.5, Fjord. (In Danish.) Available at http:// www.naturstyrelsen.dk/Vandet/Vandplaner/Se_vandplanerne/ (verified 16 June 2011). Danish Ministry of Environment, Copenhagen.

EC. 2000. Directive 2000/60/EC of the European Parliament and of the Council of 23 October 2000 establishing a framework for community action in the field of water policy. Off. J. Eur. Communities L327:1-72.

Egemose, S., and H.S. Jensen. 2009. Phosphorus forms in urban and agricultural runoff. Implications for management of Danish Lake Nordborg. Lake Reservoir Manage. 25:410-418. doi:10.1080/07438140903413228

Ellenberg, H., H.E. Weber, R. Düll, V. Wirth, W. Werner, and D. Paulissen. 1992. Zeigerwerte von Pflanzen in Mitteleuropa. Scr. Geobot. 18:1-258.

Hagerty, D.J., M.F. Spoor, and C.R. Ullrich. 1981. Bank failure and erosion on the Ohio river. Eng. Geol. 17:141-158. doi:10.1016/0013-7952(81)90080-6

Hasholt, B. 1988. On identification of sources of suspended sediment transport in small basins with special references to particulate phosphorus. p. 241-250. In M.P. Bordas and D.E. Walling (ed.) Proc. of the Symp. on Sediment Budgets, Porto Alegre, Brazil. 11-15 Dec. 1988. IAHS Publ. 174. IAHS Press, Cent. for Ecol. and Hydrol., Wallingford, UK.

Haygarth, P.M., H. ApSimon, M. Betson, D. Harris, R. Hodgkinson, and P.J.A. Withers. 2009. Mitigating diffuse phosphorus transfer from agriculture according to cost and efficiency. J. Environ. Qual. 38:20122022. doi: $10.2134 /$ jeq 2008.0102

Heathwaite, A.L., A. Sharpley, M. Bechmann, and S. Rekolainen. 2005. Assessing the risk and magnitude of agricultural nonpoint source phosphorus pollution. p. 981-1020. In J.T. Sims and A.N. Sharpley (ed.) Phosphorus: Agriculture and the environment. Agron. Monogr. 46. ASA, CSSA, SSSA, Madison, WI.

Hejzlar, J., S. Anthony, B. Arheimer, H. Behrendt, F. Bouraoui, B. Grizzetti, P. Groenendijk, M.H.J.L. Jeuken, H. Johnsson, A. Lo. Porto, B. Kronvang, Y. Panagopoulos, V. Siderius, M. Silgram, M. Venohr, and J. Zaloudík. 2009. Nitrogen and phosphorus retention in surface waters: An inter comparison of predictions by catchment models of different complexity. J. Environ. Monit. 11:584-593. doi:10.1039/b901207a

Hoffmann, C.C., and A. Baattrup-Pedersen. 2007. Re-establishing freshwater wetlands in Denmark. Ecol. Eng. 30:157-166. doi:10.1016/j. ecoleng.2006.09.022 
Hoffmann, C.C., C. Kjaergaard, J. Uusi-Kämppä, H.C.B. Hansen, and B. Kronvang. 2009. Phosphorus retention in riparian buffers: Review of their efficiency. J. Environ. Qual. 38:1942-1955.

Hooke, J.M. 1980. Magnitude and distribution of rates of river bank erosion. Earth Surf. Processes 5:143-157. doi:10.1002/esp.3760050205

Jeppesen, E., B. Kronvang, M. Meerhoff, M. Søndergaard, K.M. Hansen, H.E. Andersen, T.L. Lauridsen, B. Meryem, A. Ozen, and J.E. Olesen. 2009. Climate change effects on runoff, catchment phosphorus loading and lake ecological state, and potential adaptations. J. Environ. Qual. 38:1930-1941. doi:10.2134/jeq2008.0113

Julian, J.P., and R. Torres. 2006. Hydraulic erosion of cohesive riverbanks. Geomorphology 76:193-206. doi:10.1016/j.geomorph.2005.11.003

Kronvang, B., H.E. Andersen, C.B. Børgesen, T. Dalgaard, S.E. Larsen, J. Bøgestrand, and G. Blicher-Mathiesen. 2008. Effects of policy measures implemented in Denmark on nitrogen pollution of the aquatic environment. Environ. Sci. Policy 11:144-152. doi:10.1016/j. envsci.2007.10.007

Kronvang, B., M. Bechman, H. Lundekvam, H. Behrendt, G.H. Rubæk, O.F. Schoumans, N. Syversen, H.E. Andersen, and C.C. Hoffmann. 2005. Phosphorus losses from agricultural areas in river basins: Effects and uncertainties of targeted mitigation measures. J. Environ. Qual. 34:21292144. doi:10.2134/jeq2004.0439

Kronvang, B., H. Behrendt, H.E. Andersen, B. Arheimer, A. Barr, S.A. Borgvang, F. Bouraoui, K. Granlund, B. Grizzetti, P. Groenendijk, E. Schwaiger, J. Hejzlar, L. Hoffmann, H. Johnsson, Y. Panagopoulos, A. Lo Porto, H. Reisser, O. Schoumans, S. Anthony, M. Silgran, M. Venohr, and S.E. Larsen. 2009a. Ensemble modelling of nutrient loads and nutrient load partitioning in 17 European catchments. J. Environ. Monit. 11:572-583. doi:10.1039/b900101h

Kronvang, B., and A.J. Bruhn. 1996. Choice of sampling strategy and estimation method when calculating nitrogen and phosphorus transport in small lowland streams. Hydrol. Processes 10:1483-1501. doi:10.1002/ (SICI) 1099-1085(199611)10:11<1483::AID-HYP386>3.0.CO;2-Y

Kronvang, B., C.C. Hoffmann, and R. Dröge. 2009b. Sediment deposition and net phosphorus retention in a hydraulically restored lowland riverfloodplain in Denmark: Combining field studies with laboratory experiments. Mar. Freshw. Res. 60:638-646. doi:10.1071/MF08066

Kronvang, B., A. Laubel, and R. Grant. 1997. Suspended sediment and particulate phosphorus transport and delivery pathways in an arable catchment, Gelbæk Stream, Denmark. Hydrol. Processes 11:627-642. doi:10.1002/ (SICI) 1099-1085(199705)11:6<627::AID-HYP481>3.0.CO;2-E

Kronvang, B., N. Vagstad, H. Behrendt, J. Bøgestrand, and S.E. Larsen. 2007. Phosphorus losses at the catchment scale within Europe: An overview. Soil Use Manage. 23:104-116. doi:10.1111/j.1475-2743.2007.00113.x

Laubel, A., B. Kronvang, C. Fjorback, and S.E. Larsen. 2002. Time-integrated suspended sediment sampling from a small lowland stream. Verh. Int. Ver. Theor. Angew. Limnol. 28:1420-1424.

Laubel, A.L., L.M. Svendsen, and B. Kronvang. 1999. Stream bank erosion in a Danish lowland river system. Hydrobiologia 410:279-285. doi:10.1023/A:1003854619451

Laubel, A.R., B. Kronvang, A.B. Hald, and C. Jensen. 2003. Hydromorphological and biological factors influencing sediment and phosphorus loss via bank erosion in small lowland rural streams in Denmark. Hydrol. Processes 17:3443-3463. doi:10.1002/hyp.1302

Lawler, D.M. 1993. The measurement of river bank erosion and lateral channel change: A review. Earth Surf. Process. Landforms 17:455-463. doi:10.1002/esp.3290170505

Lawler, D.M. 2008. Advances in the continuous monitoring of erosion and deposition dynamics: Developments and applications of the new PEEP-3T system. Geomorphology 93:17-39. doi:10.1016/j. geomorph.2006.12.016
Lawler, D.M., J.R. Grove, J.S. Couperthwaite, and G.J.L. Leeks. 1999. Downstream change in river bank erosion rates in the Swale-Ouse system, northern England. Hydrol. Processes 13:977-992. doi:10.1002/ (SICI) 1099-1085(199905) 13:7<977::AID-HYP785>3.0.CO;2-5

Maguire, R.O., G.H. Rubæk, B.E. Haggard, and B.H. Foy. 2009. Critical evaluation of the implementation of mitigation options for phosphorus from field to catchment scales. J. Environ. Qual. 38:1989-1997. doi: $10.2134 /$ jeq 2007.0659

Moss, T., and J. Monstadt. 2008. Restoring floodplains in Europe: Policy contexts and project experiences. IWA Publ., London.

Owens, P.N., D.E. Walling, and G.J.L. Leeks. 2000. Tracing flucial suspended sediment sources in the catchment of the River Tweed, Scotland using composite fingerprints and a numerical mixing model. p. 291-308. In I.D.L. Foster (ed.) Tracers in geomorphology. Wiley, Chichester, UK.

Paludan, C., and H.S. Jensen. 1995. Sequential extraction of phosphorus in freshwater wetland and lake sediment: Significance of humic acids. Wetlands 15:365-373. doi:10.1007/BF03160891

Psenner, R., R. Pucko, and M. Sager. 1984. Die Fraktionierung organischer und anorganischer Phosphorverbindungen von Sedimenten. (In German.) Arch. Hydrobiol. 70:111-155.

Raven, E.K., S.N. Lane, and R. Ferguson. 2010. Using sediment impact sensors to improve the morphological sediment budget approach for estimating bedload transport rates. Geomorphology 119:125-134. doi:10.1016/j.geomorph.2010.03.012

Russell, M.A., D.E. Walling, and R.A. Hodgkinson. 2001. Suspended sediment sources in two small lowland agricultural catchments in the UK. J. Hydrol. 252:1-24. doi:10.1016/S0022-1694(01)00388-2

Schoumans, O.F., M. Silgram, D.J.J. Walvoort, P. Groenendijk, F. Bouraoui, H.E. Andersen, A. Lo Porto, H. Reisser, G. Le Gall, S. Anthony, B. Arheimer, H. Johnsson, Y. Panagopoulos, M. Mimikou, U. Zweynert, H. Behrendt, and A. Barr. 2009. Evaluation of the difference of eight model applications to assess diffuse annual nutrient losses from agricultural land. J. Environ. Monit. 11:540-553. doi:10.1039/b823240g

Shapiro, S.S., and M.B. Wilk. 1965. An analysis of variance test for normality (complete samples). Biometrika 52:591-611.

Sharpley, A.N., and S. Rekolainen. 1997. Phosphorus in agriculture and its environmental implications. p. 1-54. In H. Tunney et al. (ed.) Phosphorus loss from soil to water. CAB Int. Press, Cambridge, UK.

Simon, A., A. Curini, S. Darby, and E.J. Langendoen. 1999. Stream-bank mechanics and the role of bank and near-bank processes in incised channels. p. 123-152. In S.E. Darby and A. Simon (ed.) Incised river channels: Processes forms, engineering and management. John Wiley \& Sons Press, Chichester, UK.

Snedecor, G.W., and W.G. Cochran. 1989. Statistical methods. 8th ed. Iowa State Univ. Press, Ames.

Strahler, A.N. 1957. Quantitative analysis of watershed geomorphology. Trans. Am. Geophys. Union 8:913-920.

Stutter, M., S.J. Langan, and D.G. Lumsdon. 2009. Vegetated buffer strips can lead to increased release of phosphorus to waters: A biogeochemical assessment of mechanisms. Environ. Sci. Technol. 43:1858-1863. doi:10.1021/es8030193

Svendsen, L.M., and B. Kronvang. 1993. Retention of nitrogen and phosphorus in a Danish lowland river system: Implications for the export from the watershed. Hydrobiologia 251:123-135. doi:10.1007/BF00007172

Walling, D.E., P.N. Owens, and G.J.L. Leeks. 1998. The role of channel and floodplain storage in the suspended sediment budget of the River Ouse, Yorkshire, UK. Geomorphology 22:225-242. doi:10.1016/ S0169-555X(97)00086-X

Zaimes, G.N., R.C. Schultz, and T.M. Isenhart. 2008. J. Am. Water Resour. Assoc. 44:935-947. doi:10.1111/j.1752-1688.2008.00210.x 